
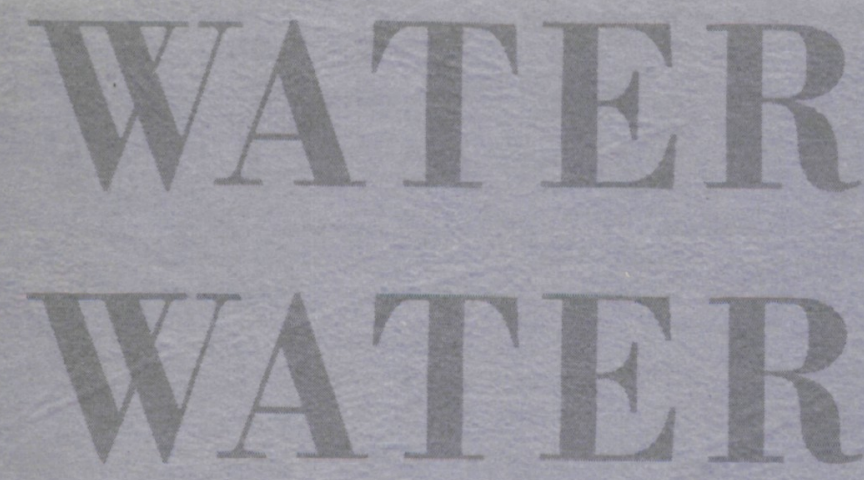

\title{
THE MECHANISM OF OZONE INACTIVATION OF WATER BORNE VIRUSES
}
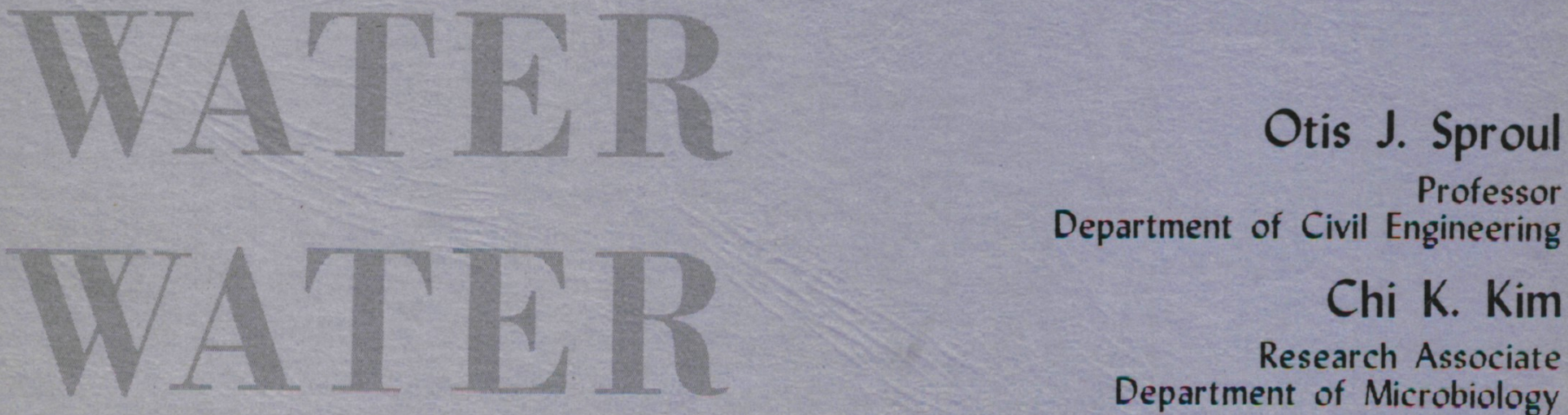

Department of Civil Engineering

Chi K. Kim

Research Associate Department of Microbiology

The Ohio State University

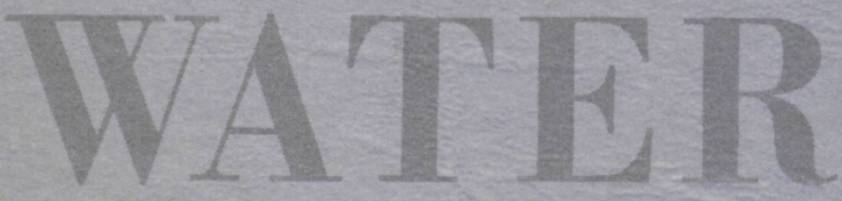

Contract No.

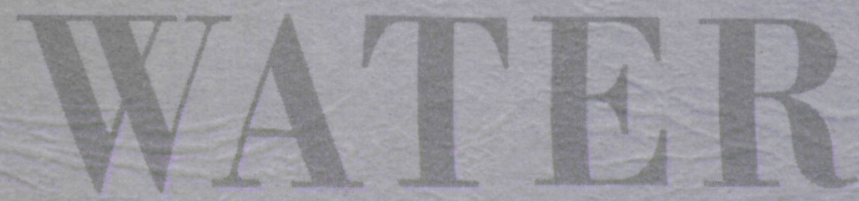
B-OI3-MAINE

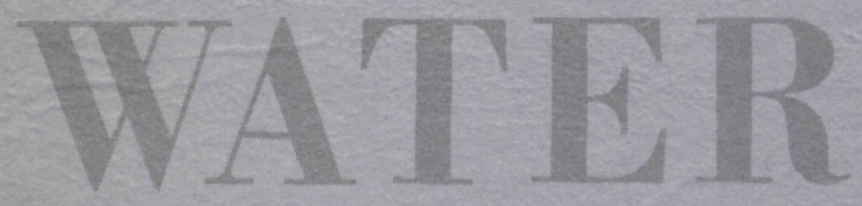

Land and Water Resources Institiute University of Maine at Orono
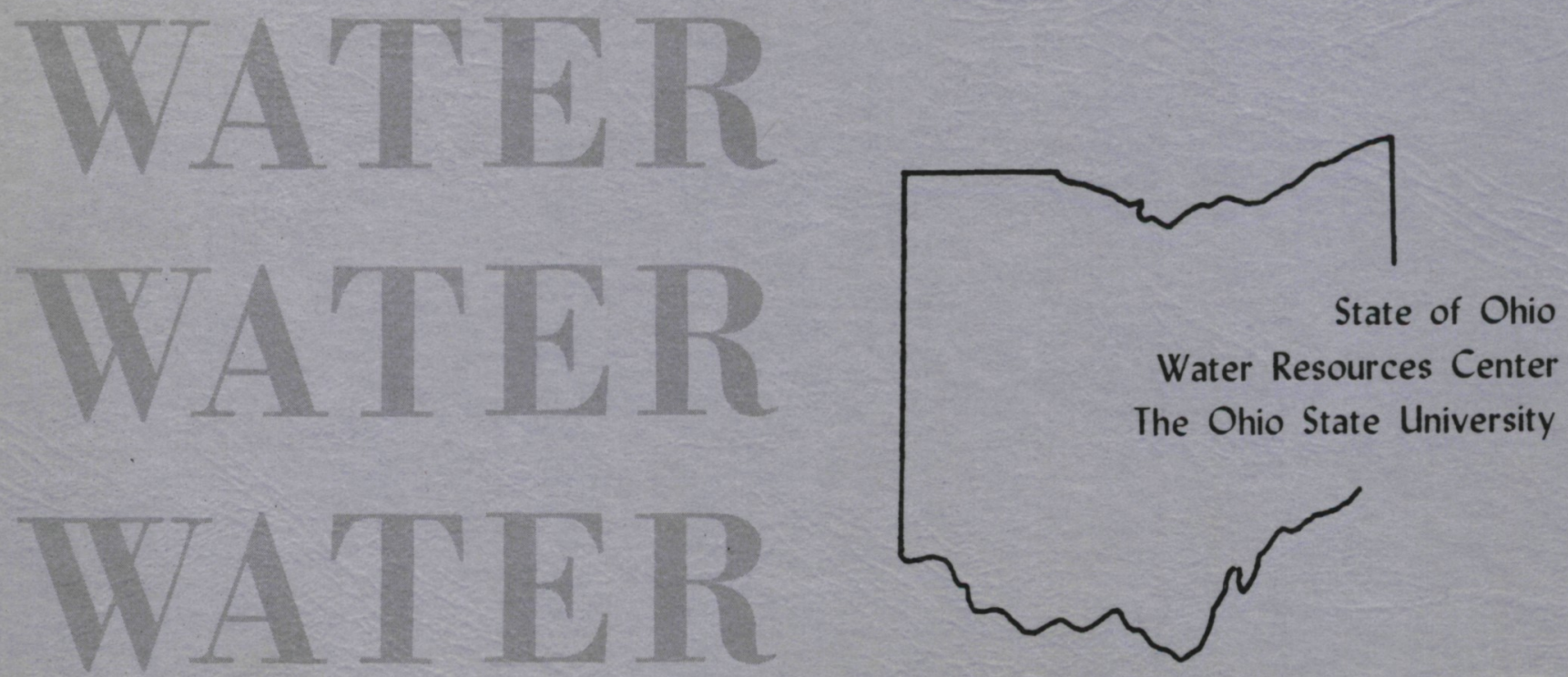



\author{
Land and Water Resources Institute \\ University of Maine at Orono \\ Water Resources Center \\ The Ohio State University
}

THE MECHANISM OF OZONE

INACTIVATION OF WATERBORNE VIRUSES

by

Otis J. Spropll
Chi K. Kiml

JuTy 1980

The work upon which this puilication is based was supported in part by funds provided by the United States Department of Interior, Office of Water Research and Technology, as authorized under the Water Resources Research Act of 1964 as amended.

1 Department of Civil Engineering The Ohio State University Columbus, $\mathrm{OH} 43210$ 


\section{ACKNIOWLEDGMENTS}

This work was supported in part by funds provided by the United States Department of Interior, Office of Water Research and Technology, as authorized under the Water Resources Research Act of 1964 as amended, Project Number B-013-ME. The authors also acknowledge contributions of the late David M. Gentile, who initiated this work while a Ph.D. candidate at the University of Maine. The Union Cartide Corporation graciously loaned the ozonator for this work.

A portion of this material was published in a paper entitled "Mechanism of Ozone Inactivation of Bacteriophage f2" in Applied and

Environmental Microbiology, volume 39, pages 210-218, January 1980. 
INTRODUCTION

Ozone has received much recent attention as an alternative disinfectant to chlorine in water and wastewater treatment practices due to its quicker, powerful germicidal activity and no reported side effects as can be produced by chlorination, such as taste, odor, and toxic byproducts (2). Inactivation kinetics with ozone have been actively studied in laboratory or pilot-plant scale using a variety of microorganisms including viruses $(12,17,32)$. Much information has accumulated attesting to its superiority over other chemical disinfectants $(10,33)$ Lower concentrations of ozone and shorter contact tines are required than are needed when using chlorine or other agents, and it is more effective than other disinfectants against resistant organisms, such as amoebic cysts and viruses.

Although the earlier all-or-none phenomenon of ozone inactivation was explained as an ozone demand exerted by the organisms themselves (23) recent reports indicate a threshold effect in virus ozonation $(11,15)$ Katzenelson and Biedermann (10) reported a two-stage inactivation of ozone, in which 99 percent of the test organisms were inactivated in 8 seconds and the remainder only after several minutes of contact. They demonstrated that their two stage kinetics could be ascribed to virus aggregation. Limited information is available on the mechanism of ozone inactivation of bacteria and viruses, even though ozone has been increasingly used in disinfection practices in water

The RNA containing bacteriophage $f 2$ which is chemically and physically very similar to enteric viruses was first introduced in 1964 (9) as a model for inactivation study of the enteric viruses. Since then, 
the phage $f 2$ has been used by many researchers $(5,21,22,28)$ for the study of inactivation kinetics and inactivation mechanisms using various disinfecting agents. Hsu et al. (9) showed that the phage f2 RNA and poliovirus RNA were resistant to iodination and that inactivation of both f2 and poliovirus were inhibited by increasing iodide ion concentration. The phage $\mathrm{f} 2$ was used by 01 ivieri et al. (21) to study the mode of action of chlorine, bromine, and iodine. They found that the mode of action depended upon the element. Chlorine inactivated naked f2 RNA at the same rate as Rivi in the intact phage at $\mathrm{pH} 7.5$ or lower. The protein of the inactivated phage was still able to adsorb to the host. Bromine inactivated the naked RNA at the same rate as the intact phage, but the RNA prepared from bromine-treated virus was significantly less inactivated than the intact virus They suggested that the primary site of bromine inactivation was more likely to be the protein moiety of the virus. Iodine functioned through iodination of the amino acid tyrosine in the protein moiety of the phage with almost no effect on the nucleic acid.

The inactivation mechanism of ozone has been only partially studied for viruses and bacteria. Using ozone in secondary effluent Pavoni et al. (22) reported that the mechanism of destruction of $f 2$ phage and bacteria was probably oxidative. Riesser et al. (26) reported that the protein capsid of poliovirus type 2 was damaged by ozonation so that uptake into the susceptible cells was inhibited. Damage of the viral protein coat was also demonstrated by DeMik and DeGroot (6), when the bacteriophage Qx 174 was exposed to air containing ozone. They also observed breaks in the phage DNA. Christensen and Giese (4) reported that the effect of ozone on nucleic acid was ascribed to $j$ ts action on the purines and pyrimidines, each of which appeared to be affected. In studies by Prat et al. 
(24) and Scott (27) using E. coli DNA, the pyrimidine base was modified by ozonation, with thymine reacting with ozone more sensitively than cytosine and uracil These reports provide limited information on the mechanisms of ozone inactivation of viruses.

\section{OBJECTIVE}

It was the objective of this research to determine the ozone inactvation mechanism for viruses in water Two bacteriophages, the f2 RNA containing virus and the T4 DNA containing virus were used as models.

\section{MATERIALS AND METHODS}

\section{Preparation, purification, and titration of viruses}

Bacteriophage f2 (ATCC $\# 15766-B$ ) was propagated using Escherichia coli K-13 Hfr (ATCC $=15766$ ) grown in Tryptone Yeast Extract (TYE) broth medium, using the ammonium sulfate method described by Loeb and Zinder (14) with minor modifications. Bacteriophage T4 was prepared using $\underline{E}$. coli $S / 6 / 5$ grown in nutrient broth (H-broth) using the method of Snustad and Dean (31). The f2 phage was further purified using cesium chloride at a concentration of $0.65 \mathrm{~g} / \mathrm{ml}$ and centrifuged at a speed of 125,000 $\mathrm{x}$ $g$ for 48 hours in a Beckman L2-65B ultracentrifuge equipped with a Ti-75 rotor (Beckman Instruments Inc., Palo Alto, CA). The phage band was collected from the middle of the tube and dialyzed twice against 11 of $0.01 \mathrm{M}$ phosphate buffer containing $8.0 \mathrm{~g} / 1 \mathrm{NaCl}, \mathrm{pH} 72$, at $4^{\circ} \mathrm{C}$ for 24 hours. The dialyzate was diluted with sterile triple distilled water to about $5.0 \times 10^{12}$ plaque forming unit (PFU) per milliliter and stored at $-70^{\circ} \mathrm{C}$ until used. The T4 was purified and stored in similar fashion 
except that cesium chloride in a concentration of $0.75 \mathrm{~g} / \mathrm{ml}$ was used and was centrifuged at $40,000 \times \mathrm{g}$ for 40 hours. After dialys is the T4 concentration was $10^{10}-10^{11} \mathrm{PFU} / \mathrm{ml}$. The phage were titrated with their hosts according to the overlay method of Adams (1)

Incorporation of tritium into bacteriophage $\mathrm{f2}$

The RIIA was labeled with $\left[{ }^{3} \mathrm{H}\right]$ uridine in general accordance with the method described by Oeschger and Nathans (20). One liter of TPG medium with low uridine $(2.4 \mathrm{mg} / 1)$ was inoculated with $50 \mathrm{ml}$ of overnight grown E. coli $K-12 C-3000-38$ which is a mutant requiring uridine, thymine, and the amino acids, arginine, lysine, and histidine. After 24 hours incubation with aeration at $37^{\circ} \mathrm{C}$, the culture was amended with $3 \mathrm{mCi}$ of $[3 \mathrm{H}]$ uridine (New England Nuclear, Boston, MA) After an additional 30 minutes of incubation, the culture was infected with bacteriophage f2 at a multiplicity of infection (MOI) of 10 and incubated for another 24 hours. The tritiated phages were isolated by the method of Yamamoto and Alberts (36) using polyethylene glycol 6,000. They were further purified by ultracentrifugation on cesium chloride, dialyzed, and stored in the manner previously described.

Preparation and assay of infectious nucleic acid

Infectious RNA was prepared from the bacteriophage f2 with the phenol method described by Hofschneider and Delius (8) The RNA isolated from $2 \mathrm{ml}$ of the tritiated $\mathrm{f} 2$ was diluted to $2 \mathrm{ml}$ with cold sterile triple distilled water The RNA to be treated with ozone was subsequently extracted six times with $2 \mathrm{ml}$ of ethyl ether to remove traces of phenol After the final extraction, the residual ether was removed by bubbling with nitrogen gas. All of the RNA preparation procedures were carried 
out in an ice bucket.

The infectivity of the $f 2$ control and ozone treated RNA and the DNA recovered from the T4 samples was assayed using freshly prepared spheroplasts of their respective hosts by the method described by Hofschneider and Delius (8).

\section{Ozonation procedures}

The ozonation system used in this study is shown in Figure 1 Ozone was produced by a Linde model SG-4050 ozone generator (Union Carbide Corp., South Plainfield, NJ) The circulation system for the ozone produced was constructed with stainless steel and teflon tubing. A 21 borosilicate glass bottle was used as the reactor 0zone was dissolved in 11 of sterile ozone demand-free $10^{-3} \mathrm{M}$ phosphate buffer containing $0.01 \mathrm{M} \mathrm{NaCl}, \mathrm{pH} 7.0$, at $25 \pm 1^{\circ} \mathrm{C}$. Ozone in the off gas was neutralized by passage through a solution containing $500 \mathrm{~g}$ sodium thiosulfate and a $10 \mathrm{~g}$ potassium iodide per 3.781 water 0zone concentration was measured with a Spectronic 20 spectrophotometer (Bausch and Lomb, Inc., Rochester, NY) according to the method described by Shechter (30). All of the glassware used in this work was rendered ozone demand-free by soaking in a $>2 \mathrm{mg} / \mathrm{l}$ ozone solution for at least 1 hour, washed several times with distilled water, rinsed with triple distilled water, and dried at $110^{\circ} \mathrm{C}$ for 5 hours. The bacteriophages and f2 RNA were treated with ozone solution at a ratio of 1 to 100 in the reactor bottle or in a test tube at $25 \pm 1{ }^{\circ} \mathrm{C}$. At appropriate intervals the ozone treated phages and $\mathrm{f} 2 \mathrm{RNA}$ were transferred to a $0.206 \mathrm{~g} / 1$ sterile sodium thiosulfate solution in a volume of one-tenth of the sample to immediately neutralize the residual ozone. The control phages and f2 RNA samples were mixed with the phosphate buffer and sodium thiosulfate solution at the same ratio as in the ozone 


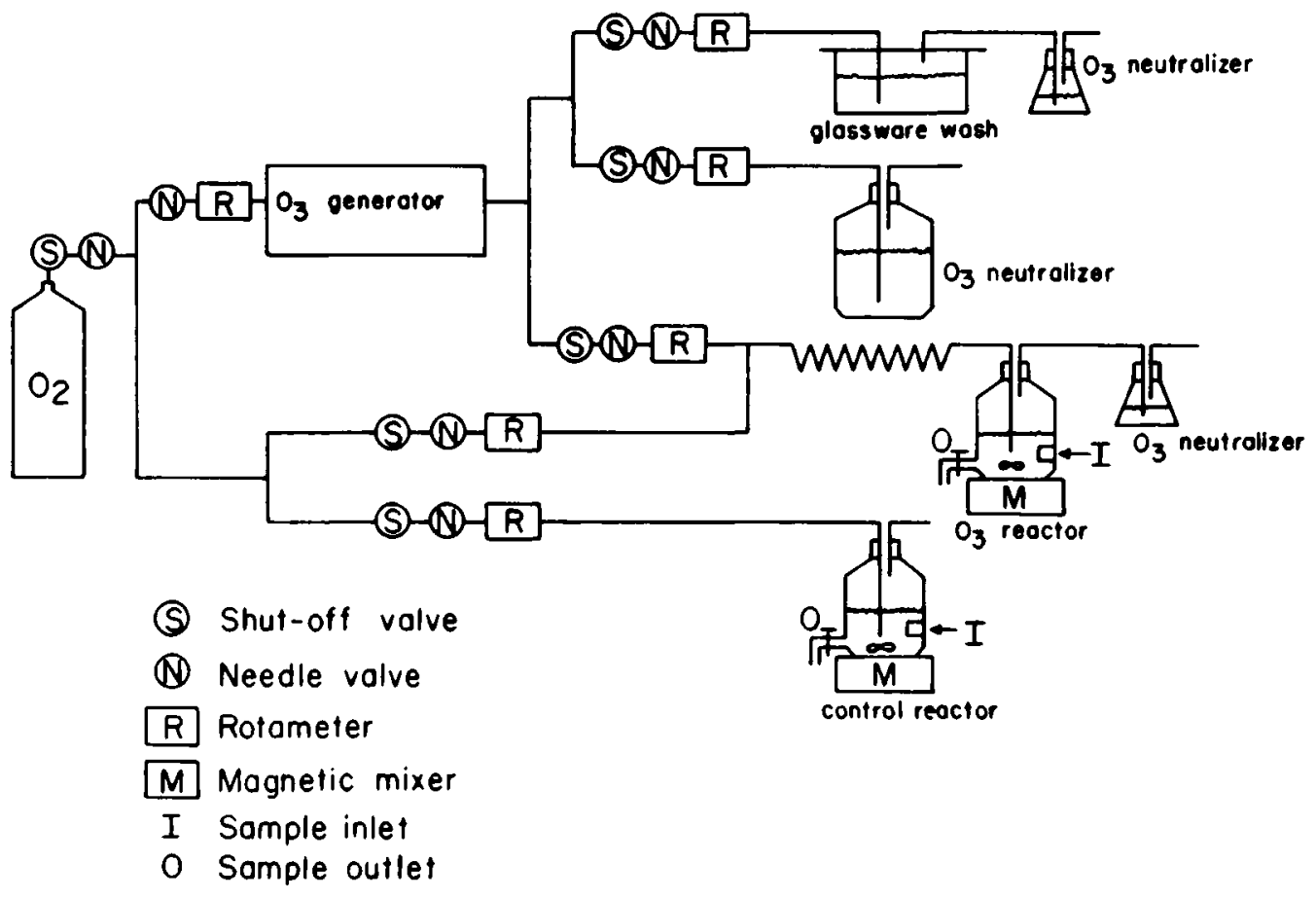

Figure 1. Ozonation system for inactivation of viruses. 
treated samples.

f2 host adsorption experiment

The procedures of Brinton and Beer (3) were used to determine the loss of adsorption capability of the ozonated virus. The E. coli $\mathrm{K}-15 \mathrm{~T}^{-}$ is not a host for the $f 2$ and any adsorption would be non-specific resulting from ozone induced changes in the phage. One milliliter samples of the control and ozone-treated phage were mixed with $1 \mathrm{ml}$ of $\underline{E}$. coli $\mathrm{K}-13$ and E. coli $\mathrm{K}-15 \mathrm{~T}^{-}$in TYE broth medium $\left(5 \times 10^{7} \mathrm{cell} / \mathrm{s} / \mathrm{ml}\right)$ for 10 minutes at room temperature. This mixture and a phage control were filtered at a vacuum of 10 inch of mercury and washed four times with $2 \mathrm{ml}$ of TYE medium through a $0.45 \mathrm{\mu m}$ Type HA Millipore filter membrane (Millipore Corp., Bedford, MA) which had been pretreated with $1 \mathrm{ml}$ of 3 percent bovine serum albumin. The filter membranes were dried for 15 minutes at $85^{\circ} \mathrm{C}$, placed in $10 \mathrm{ml}$ of Liquifluor cocktail (New England Nuclear, Boston, $M A)$, and the radioactivity counted for 5 minutes with a Packard Tri-carb model 3375 liquid scintillation spectrometer (Packard Instruments Co. Inc., Downers Grove, IL).

\section{Electron microscopy}

The f2 control and ozone-treated viruses were observed with an electron microscope alone or after mixing with the host bacteria. One $\mathrm{ml}$ portions of the control $\left(5 \times 10^{9} \mathrm{PFU} / \mathrm{ml}\right)$ and ozone-treated phages were mixed with $1 \mathrm{ml}$ of E. Coli $K-13\left(5 \times 10^{6} \mathrm{cells} / \mathrm{ml}\right)$ for 10 minutes at room temperature. One drop of the mixtures was put on a formvar and carbon coated 300 mesh copper grid (Ladd Research Ind., Inc., Burlington, VT) and dried 30 minutes. Excess water was drained with fi]ter paper and the virus and bacteria negatively stained with 2 percent uranyl acetate 
for 3 minutes After draining the excess stain and air drying, the grids were examined with a Phillips EM 300 electron microscope (Phillips Electronics, Cincinnati, $\mathrm{OH})$ at an accelerating voltage of $80 \mathrm{kv}$.

The control and ozonated T4 viruses were negatively stained with uranyl acetate and observed in the electron microscope as for the f2 virus. Where it was desired to observe DNA the sample was placed on the grid using the DNA spreading technique of Kleinschmidt (13), rotary shadowed with gold and photographed.

\section{Sucrose density gradient analysis}

Sucrose gradients were made with 5-17 or 5-20 percent sucrose in $0.01 \mathrm{M}$ phosphate buffer containing $8.0 \mathrm{~g} / 1 \mathrm{NaCl}, \mathrm{pH} 7.2$. One $\mathrm{ml}$ portions of the $f 2$ control or ozone-treated $f 2$ phage and RNA samples which had been labeled with $\left[{ }^{3} \mathrm{H}\right]$ uridine were placed on top of an $11 \mathrm{ml}$ gradient and centrifuged at a speed of 110,000 or $149,000 \times g$ for 4 or 8 hours at $4^{\circ} \mathrm{C}$ with a Beckman L2-65B ultracentrifuge using an SW 41 rotor (Beckman Instruments, Inc., Palo Alto, CA) The gradient was fractionated by collecting 15, 25 or 50 drops for each fraction with an ISCO density gradient fractionator model 180 (Instrumentation Specialties Co. Inc., Lincoln, NE) using a 40 percent sucrose solution. Each fraction was examined for refractive index, infectivity of the phage, and radioactivity. The phages in the fractions were titrated after dialyzing against 0.01 $M$ phosphate buffer containing $8.0 \mathrm{~g} / 1 \mathrm{NaCl}, \mathrm{pH} 7.2$, at $4^{\circ} \mathrm{C}$ overnight. Ten $\mathrm{ml}$ of Biofluor cocktail (New England Nuclear, Boston, MA) were mixed with each fraction and radioactivity was counted in the same way previously described. 


\section{RESULTS}

\section{f2 bacteriophage}

The ozone inactivation kinetics of bacteriophage $f 2$ are shown in Table 1 A rapid phage inactivation during the first 5 seconds of exposure was noted with 5 logs lost at $0.09 \mathrm{mg} / 1$ ozone and by greater than 7 logs at $0.8 \mathrm{mg} / 1$ ozone. During the next 10 minutes, the $f 2$ phages were gradually inactivated at a slower rate in both ozone concentrations The specific and non-specific adsorption of those phage samples examined by the filtration method are shown in Table 1 The specific adsorption of the phages to the host $\underline{E}$. coli $K-13$ was gradually reduced at a slower rate in $0.09 \mathrm{mg} / 1$ ozone solution and faster in $0.8 \mathrm{mg} / 1$ ozone. In both treatments the general trends of reduction in the specific adsorption of the phages were faster for the first 5 seconds and slower for the next 10 minutes, and were similar to the reduction in PFU. On the other hand, non-specific adsorption of the phages to the non-host female strain E. coli K-15 $\mathrm{T}^{-}$and to the cellulose nitrate filter membrane was not significantly changed by ozonation at either ozone concentration.

The untreated control phages and the phage samples which had been treated with $0.09 \mathrm{mg} / 1$ ozone for 5 seconds (referred to as light treatment) and $0.8 \mathrm{mg} / 1$ ozone for 30 seconds (referred to as heavy treatment) were sedimented in a 5-20 percent sucrose gradient and fractionated by collecting 25 drops for each fraction. On the other hand, the $f 2$ phage RNA was first extracted from the stock phages and then lightly or heavily treated with ozone. The naked RNA samples were sedimented and fractionated in the same manner as in the phage samples. The PFU of the phages and radioactivity of the phage and naked RNA are shown in Figure 2 . The 
Table 1. Ozone inactivation kinetics of bacteriophage $f 2$ and $i$ ts adsorption to host and non-host bacteria and to cellulose nitrate filter.

\begin{tabular}{|c|c|c|c|c|c|c|c|c|c|c|}
\hline \multirow{2}{*}{$\begin{array}{l}\text { Reaction } \\
\text { time } \\
\text { (sec) }\end{array}$} & \multirow{2}{*}{$\begin{array}{c}\text { Residual } \\
\text { ozone } \\
(\mathrm{mg} / 1)\end{array}$} & \multirow{2}{*}{$\begin{array}{c}\text { Survival of } \\
\text { f2 phage } \\
(\text { PFU/ml) }\end{array}$} & \multicolumn{3}{|c|}{$\begin{array}{c}\text { Adsorption of f2 phage } \\
\text { (CPM) to }\end{array}$} & \multirow{2}{*}{$\begin{array}{c}\text { Residual } \\
\text { ozone } \\
(\mathrm{mg} / 1)\end{array}$} & \multirow{2}{*}{$\begin{array}{l}\text { Survival of } \\
\text { f2 phage } \\
\text { (PFU/mi) }\end{array}$} & \multicolumn{3}{|c|}{$\begin{array}{l}\text { Adsorption of f2 phage } \\
\text { (CPM) to }\end{array}$} \\
\hline & & & $\frac{E}{k-13}$ & $\frac{E}{K} \cdot 1 \frac{C 01 i}{5 T^{-}}$ & $\begin{array}{c}\text { filter } \\
\text { membrane }\end{array}$ & & & E. $\frac{\text { coli }}{K-13}$ & $\frac{E}{K} \cdot 1 \frac{C 01 i}{5 T^{-}}$ & $\begin{array}{l}\text { filter } \\
\text { membrane }\end{array}$ \\
\hline 0 & 0.09 & $5.3 \times 10^{9}$ & 2617 & 53 & 139 & 0.80 & $5.3 \times 10^{9}$ & 2617 & 53 & 139 \\
\hline 5 & $-b$ & $8.7 \times 10^{4}$ & 1742 & 103 & 88 & - & $2.6 \times 10^{3}$ & 1013 & 185 & 79 \\
\hline 10 & 0.086 & $6.2 \times 10^{4}$ & 1777 & 122 & 73 & 0.75 & $6.8 \times 10^{2}$ & 851 & 103 & 74 \\
\hline 30 & 0.085 & $3.3 \times 10^{3}$ & 1660 & 170 & 81 & 0.68 & $5.2 \times 10^{2}$ & 562 & 89 & 69 \\
\hline 60 & 0.083 & $5.6 \times 10^{2}$ & 1363 & 101 & 84 & 0.64 & $2.0 \times 10^{0}$ & 434 & 74 & 66 \\
\hline 120 & 0.08 & $5.0 \times 10^{2}$ & 1457 & 144 & 77 & 0.53 & $1.0 \times 10^{0}$ & 372 & 61 & 57 \\
\hline 600 & 0.065 & $4.6 \times 10^{1}$ & 1199 & 165 & 67 & 0.30 & 0 & 283 & 52 & 58 \\
\hline
\end{tabular}

${ }^{a}$. coli K-13 and E. coli K-15T- were used, respectively, as the host and non-host bacteria of the phage f2. A $0 . \overline{45} \mathrm{~mm}$ Millipore type HA membrane filter was used for non-specific adsorption of the phages.

$-{ }^{b}$ Not determined. 


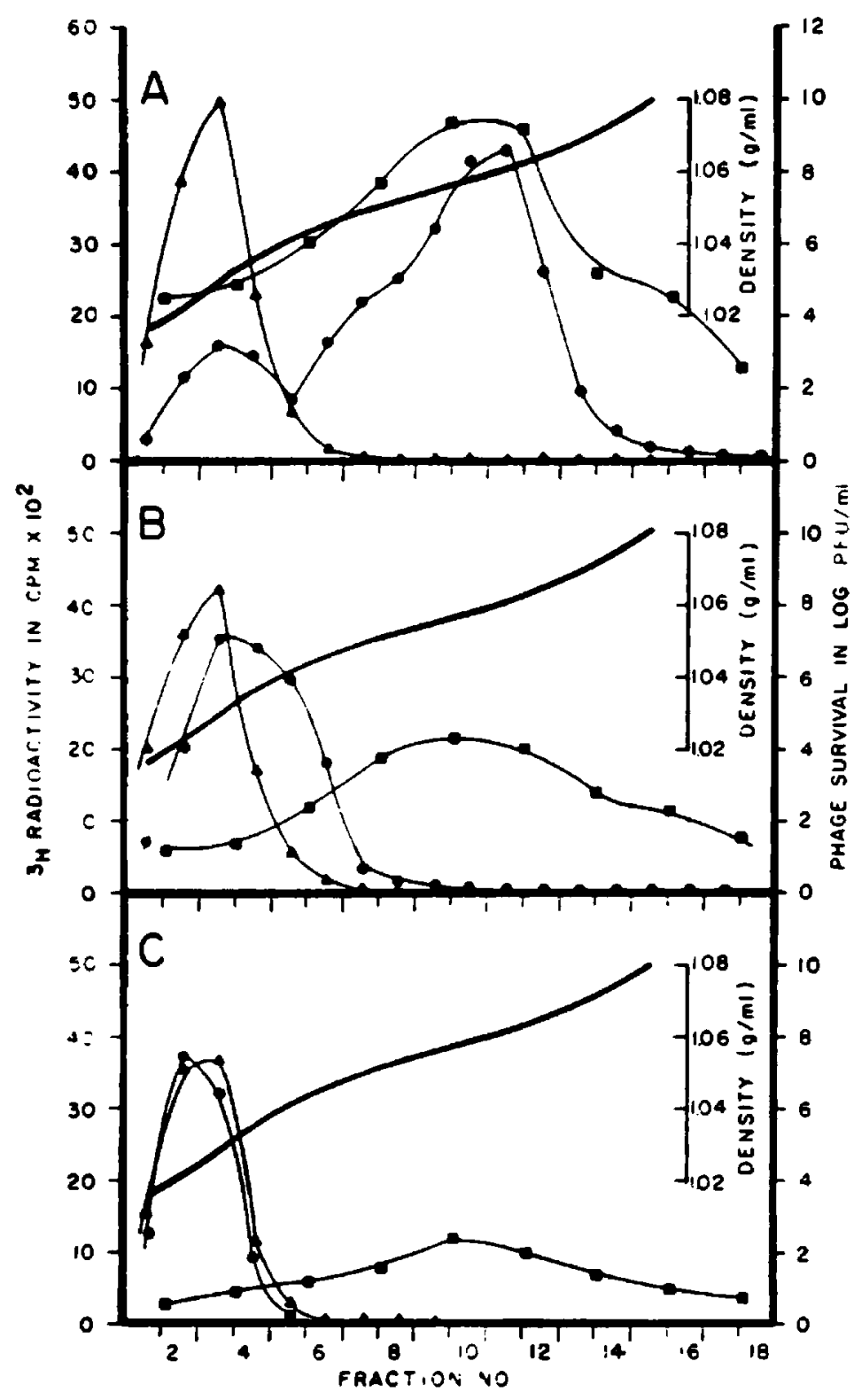

Figure 2. Sucrose density gradient analysis of untreated control bacteriophage $f 2(A)$ and samples which were treated with $0.09 \mathrm{mg}$ of ozone per liter for $5 \mathrm{~s}$ (B) and with $0.8 \mathrm{mg}$ of ozone per liter for $30 \mathrm{~s}$ (C). The naked RNA which had been extracted from the stock phage was ozonated in the same manner as the phage. Three separate gradients were used to measure the radioactivities of phage and naked RNA and phage infectivity. Both samples of phage and naked RNA were centrifuged at $110,000 \times \mathrm{g}$ for $4 \mathrm{~h}$ in a 5 to $20 \%$ sucrose gradient. For each fraction 25 drops was collected from the top to analyze the radioactivity of the phage (0) and the naked RNA ( $\Delta)$ For each fraction 50 drops was collected for titration of phage infectivity ( $)$ (The peaks of PFUs remained in the mixture of fractions 9 and 10 after ozonation, whereas the radioactivity peaks of the samples were moved up by ozonation. The radioactivities of all naked RNA samples were essentially unchanged, showing their peaks in fraction 3. Note a minor radioactivity peak of the control phage sample in fraction 3. 
peaks of the PFU curves in the control and ozone-treated phage were found in the mixture of the 9 th and 10th fractions in all three samples, showing reduced PFUs in the samples which had been treated at the heavier concentration of ozone for a longer time. However, the radioactivity (presence of the f2 RNA) in the ozone-treated phages was localized in the upper fractions with lighter density. The radioactivity of the control phage was found mainly in the same gradient fractions in which the peak of the PFU curve was seen (Figure $2 A$ ), but the radioactivity in the lightly and heavily treated phage samples was observed in the 3rd and 4 th fractions and 2 nd and 3 rd fractions, respectively (Figures $2 B$ and 2C). The radioactivities of the control naked RNA as well as the ozonetreated naked RNA samples were nearly the same, showing their peaks in the 2nd and 3rd fractions in all three samples. The distribution of heavily treated naked radioactive RNA was identical to that of the heavily treated phage sample (Figure $2 \mathrm{C}$ ), thereby indicating that the RNA from the ozonated phage had been liberated into the water.

In order to prove a leakage of RNA from the phages during ozonation and to correlate the specific adsorption of the ozone-treated phages to the inactivation rate of the phages, the control and ozone-treated phages were mixed with the host bacteria and observed with an electron microscope (figure 3). The control phages had the integrity of the icosahedral structure and attached to pili of the host (Figure $3 \mathrm{~A}$ ) The phages unadsorbed to the pili were scattered over the grid as single particles. A few broken particles were also observed in the control sample. In the phage samples which had been lightly treated with ozone, some broken phage particles were seen, while other intact phages were attached to the pili (Figure 3B). Almost all the phages were disrupted in the heavily 


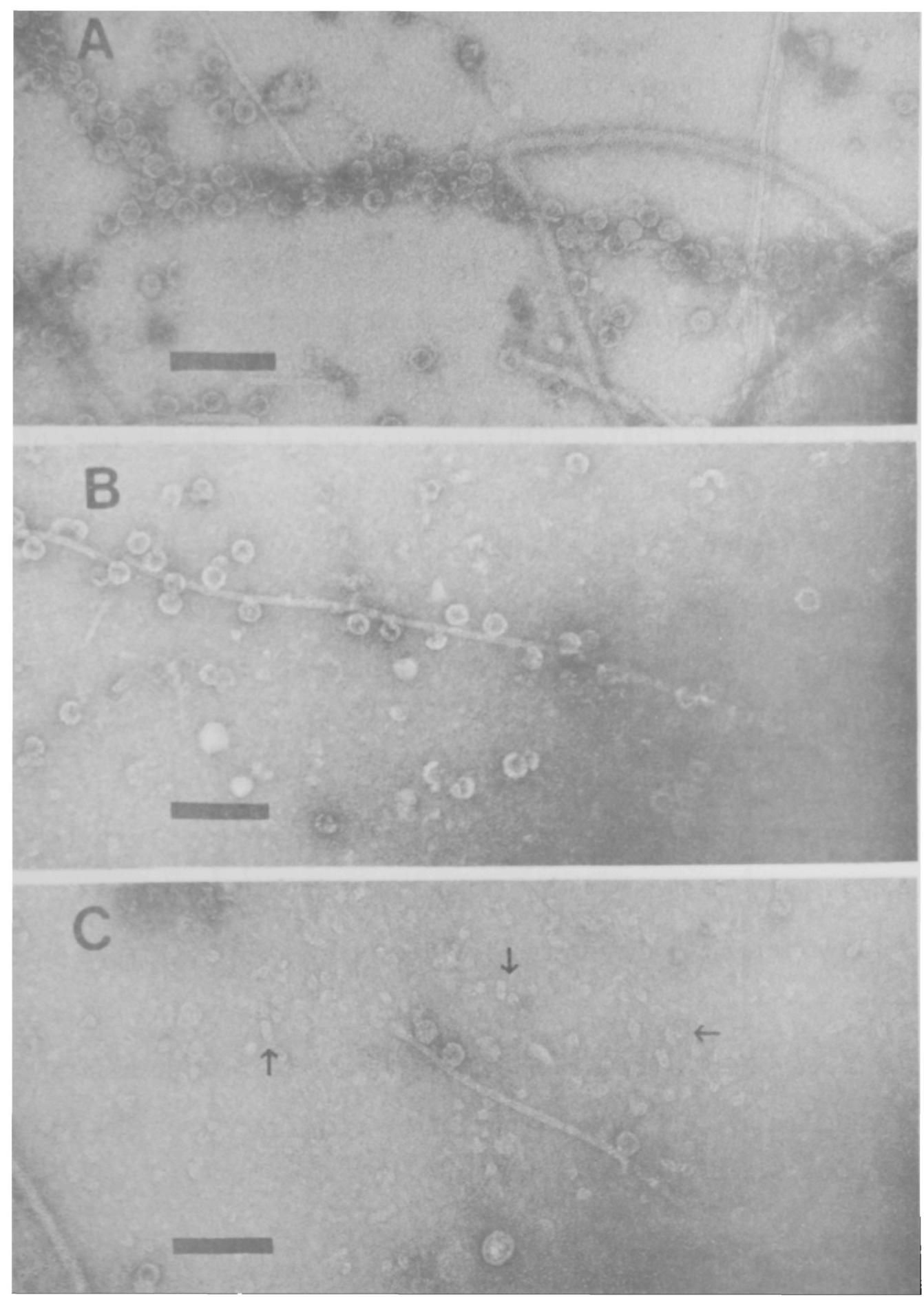

Figure 3. Electron micrographs of control phage $f 2(A)$ and phage which were treated with $0.09 \mathrm{mg}$ of ozone per liter for $5 \mathrm{~s}$ (B) and with $0.8 \mathrm{mg}$ of ozone per liter for $30 \mathrm{~s}$ (C) The phage samples adsorbed to the host bacteria were stained with $2 \%$ uranyl acetate. The control sample showed that almost all of the phage were intact and that many of them adsorbed to the host pili. A few of them are seen partially damaged. Some of the lightly treated phage were still intact and adsorbed to the pili, but others were broken down to larger pieces of protein capsid. Most of the heavily treated phage were broken down to many subunits of the capsid, and only a few of them can be seen intact and adsorbed to the pili or unadsorbed. Many subunits (arrows) of tine protein capsid are seen all over the grid. Bars - $0.1 \mu \mathrm{m}$. 
treated sample (Figure $3 \mathrm{C}$ ) with only a few intact phages found in the background or attached to the pili Many subunits (arrows) of the protein capsid were observed in the heavily treated phage sample as seen in Figure $3 C$.

The survival fractions of the phage and naked RNA samples were examined after ozonation and compared with the RNA extracted from the phages previously treated with ozone (Figure 4). In the case of light ozone treatment, the RNA extracted from the ozone-treated phages (about 5 logs of inactivation) showed about 3 logs of inactivation, but the separately treated naked RNA lost less than 1 log during ozonation (Figure $4 A$ ). In the sample of heavy treatment, the phages, the RNA extracted fron the treated phages, and the naked RNA showed respectively, over 7 logs, 5 logs, and 2 logs of inactivation (Figure 4B) In both treatments the naked RNA was much less inactivated by ozonation than the RNA inside the phage particle.

To examine any difference in inactivation rates between naked RNA and RNA enclosed in the phage coat the ozone-treated and untreated samples of both RNAs were sedimented in 5-17 percent sucrose gradients and fractionated by collecting 15 drops for each fraction. The sucrose density gradient analysis is shown in Figure 5. In the naked RNA samples (Figure $5 \mathrm{~A}$ ), the sedimentation velocity of the ozone-treated naked RNA has been slightly changed, showing their radioactivity peaks in the upper fractions with lighter buoyant density. On the other hand, the RNA extracted from the previously ozone-treated phages was sedimented at a slower rate after ozonation than those of the naked RNA (Figure 5B) The CPMs were significantly reduced in the RNA samples extracted from the previously ozonated phages as seen in Figure 5B. The difference of the 


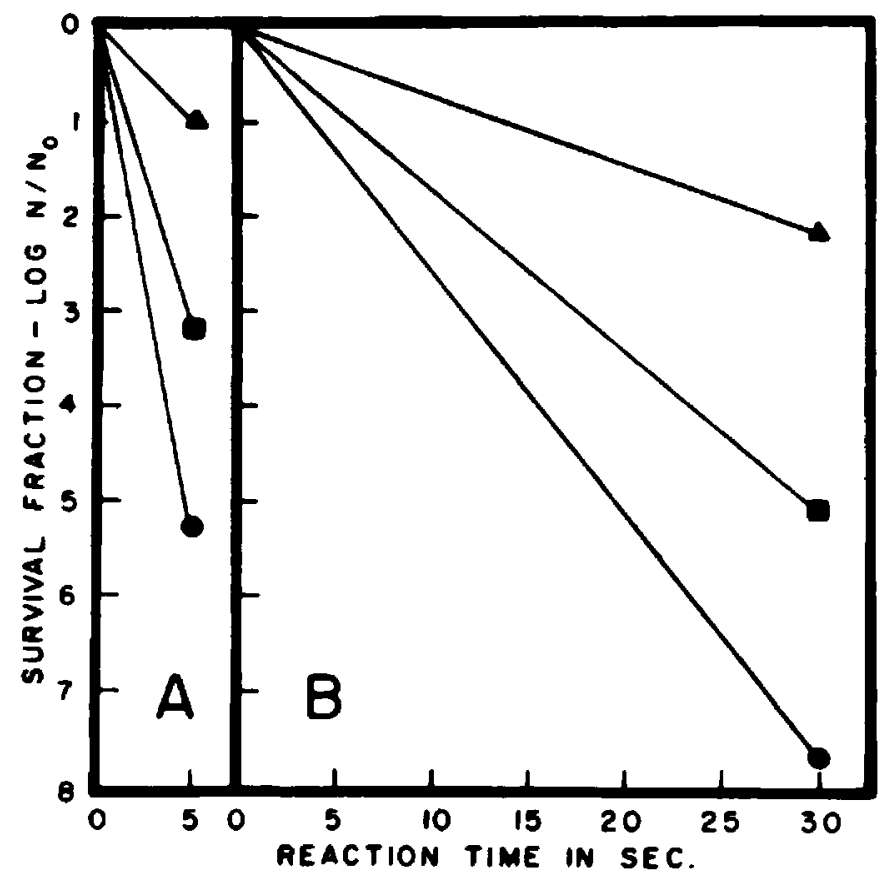

Figure 4. Comparative survival fractions of phage $f 2(0)$, RNA extracted from phage previously treated with ozone ( $\left.\sigma^{\prime}\right)$, and naked RNA (A) The samples were treated with $0.09 \mathrm{mg}$ of ozone per liter for $5 \mathrm{~s}$ (A) and with $0.8 \mathrm{mg}$ of ozone per liter for $30 \mathrm{~s}$ (B) The RNA extracted from the ozone-treated phage was less inactivated than the phage and more inactivated than the naked RNA in both treatments. 


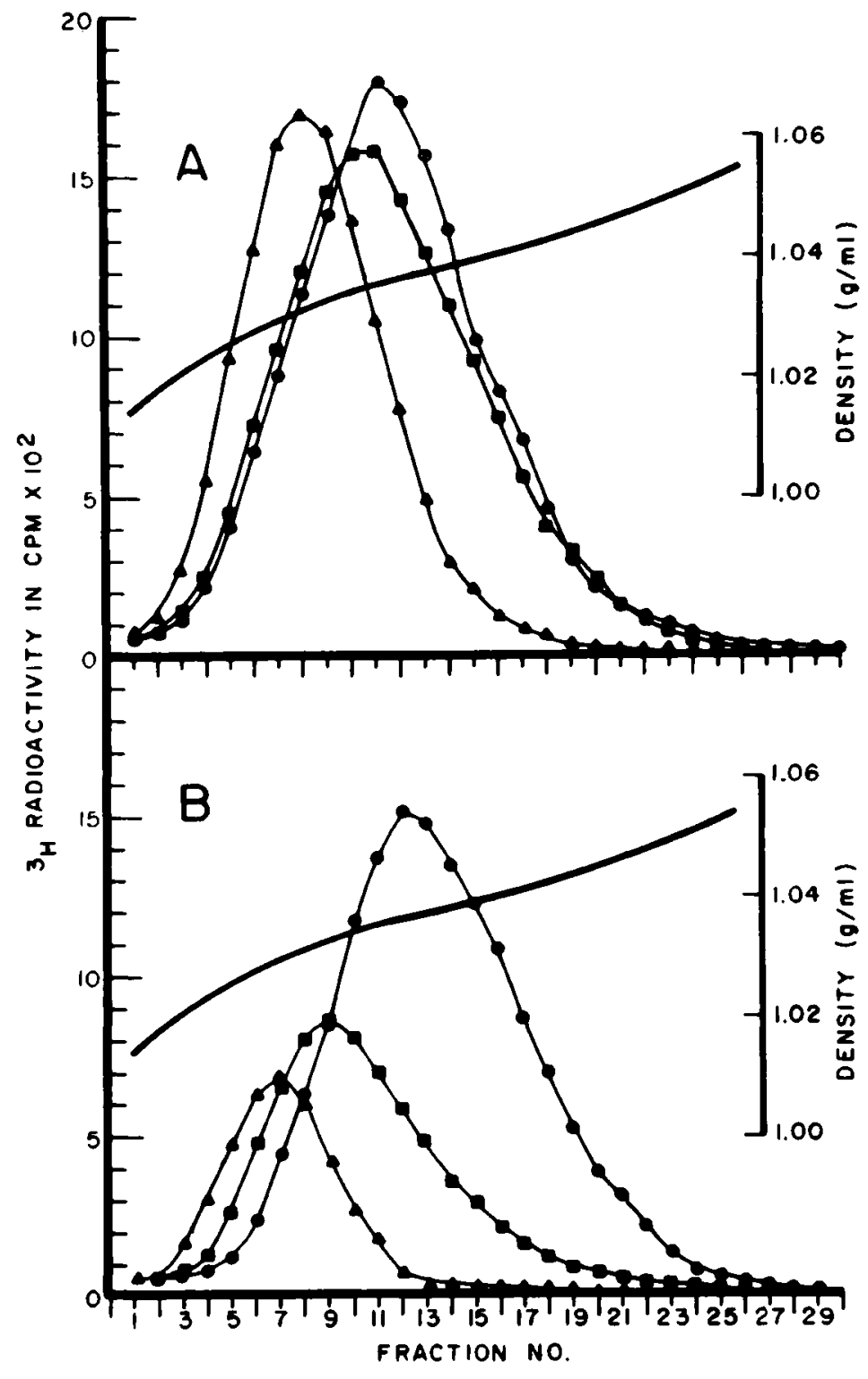

Figure 5. Sucrose density gradient analysis of ozonated naked RNA (A) and RNA extracted from the phage previously treated with ozone (B). The control RNA (O) and the RNA which had been treated with $0.09 \mathrm{mg}$ of ozone per liter for $5 \mathrm{~s}(\boldsymbol{\theta})$ and with $0.8 \mathrm{mg}$ of ozone per liter for $30 \mathrm{~s}$ (A) were centrifuged in a 5 to $17 \%$ sucrose gradient at $149,000 \times \mathrm{g}$ for $8 \mathrm{~h}$ and 15 drops for each fraction were collected from the top. The RNA extracted from the ozone-treated phage is seen in the upper fractions, which have a lower buoyant density and are lower in counts per minute than the naked RNA in both treatments. 
change of sedimentation velocity between the naked RNA and RNA extracted from the previousiy ozone-treated phages were in agreement with the results shown in Figure 4, indicating that the naked RNA was less affected by ozone than the RNA in the intact phage. The radioactivity distributions of both groups of RNA after ozonation were shifted toward fractions with lighter density, depending upon the ozone concentration and time period of the reaction.

\section{T4 bacteriophage}

The inactivation kinetics of the T4 bacteriophage and its DNA are shown in Table 2. The T4 inactivation before centrifugation appeared to be two stage since about 3 logs were lost in 5 seconds with only an additional 4 logs in the next 115 seconds. The two stage interpretation is complicated by the decrease in the residual ozone concentration from $0.46 \mathrm{mg} / 1$ to less than $0.26 \mathrm{mg} / 1$.

The T4 DNA was separated from the T4 phage by centrifugation. Four $\mathrm{ml}$ of the control and ozonated samples were cushioned on $1 \mathrm{ml}$ of $\mathrm{CsCl}$ $(1.463 \mathrm{gm} / \mathrm{ml})$ and centrifuged at $108,000 \times \mathrm{g}$ for 90 minutes in an SW 50.1 rotor with the Beckman L2-65B ultracentrifuge. The top $3 \mathrm{ml}$ containing the DNA were mixed and 0.1 ml samples taken for DNA titration. The bottom two $\mathrm{ml}$ containing the phages were mixed and sampled for virus titer

The $7.8 \times 10^{3} \mathrm{PFU} / \mathrm{ml}$ of T4 DNA in the control sample which had not been exposed to ozone were lost from the phage during handling procedures. This DNA and any released from the phages during the ozonation was rapidly inactivated by the ozone since none accumulated in the reactor and none was detected after 120 seconds 
Table 2. Ozone inactivation kinetics of Bacteriophage T4 and its DNA

\begin{tabular}{|c|c|c|c|c|c|}
\hline \multirow{3}{*}{$\begin{array}{l}\text { Reaction } \\
\text { time } \\
(\sec )\end{array}$} & \multirow{3}{*}{$\begin{array}{l}\text { Residual } \\
\text { ozone } \\
(\mathrm{mg} / 1)\end{array}$} & \multicolumn{4}{|c|}{ Plaque forming unit /ml } \\
\hline & & \multirow{2}{*}{$\begin{array}{c}\text { phage T4 } \\
\text { before } \\
\text { centrifugation }\end{array}$} & \multicolumn{3}{|c|}{ after centrifugation } \\
\hline & & & phage $T 4$ & phage & T4 DNA \\
\hline 0 & 0.46 & $3.1 \times 10^{8}$ & $2.6 \times 10^{8}$ & 7.8 & $\times 10^{3}$ \\
\hline 5 & & $2.3 \times 10^{5}$ & $9.2 \times 10^{4}$ & 2.0 & $\times 10^{1}$ \\
\hline 30 & & $1.5 \times 10^{3}$ & $8.2 \times 10^{2}$ & 1.0 & $\times 10^{1}$ \\
\hline 60 & 0.26 & $-\mathbf{a}$ & - & & - \\
\hline 120 & & $2.0 \times 10^{1}$ & $2.0 \times 10^{1}$ & & 0 \\
\hline
\end{tabular}

$-{ }^{a}$ Not determined. 
Figure 6 presents electron micrographs of the T4 phage exposed to ozone conditions shown in Table 2. The samples were not centrifuged before placing on the electron microscope grids. The control in figure 6A shows the typical T4 with head, extended sheath and baseplate structures The extensive destruction of the T4 with only 5 seconds of exposure to $0.46 \mathrm{mg} / 1$ of ozone is shown in Figure 6B. The DNA has been released from the heads with a contraction of the sheath. Most of the sheaths have been bent at the head and the baseplates have been separated. At 30 seconds of exposure to ozone (Figure 6C) nearly all of the contracted sheaths have been separated from the heads. Some of the separated sheaths were shortened further and showed a hole in the center The two minute treated phages had further rounding of the heads with a dissociation of the heads into smaller pieces. Sheaths were broken into pieces which were not discernible in the micrographs.

Further evidence of T4 phage destruction is presented in Figure 7 These micrographs were prepared by a DNA spreading technique then shadowed with gold. The control phage in Figure 7A showed occasional defective heads ( 1 ight colored) from which the DNA had been lost. Some DNA is visible in the micrograph. Destruction of the phage head, contracted sheaths and DNA lost from the heads are shown in Figure 7B after 5 seconds exposure to $0.46 \mathrm{mg} / 1$ ozone. Additional loss of head structure and DNA destruction after 2 minutes of ozone contact is evident in Figure $7 C$.

DNA destruction by exposure to ozone is detailed in Figure 8 . DNA from a phage head ruptured during handling in the control reactor is presented in Figure $8 A$. The long chain characteristic of the DNA molecule is obvious. Breaks in the chain after exposure to $0.46 \mathrm{mg} / \mathrm{l}$ of ozone for 


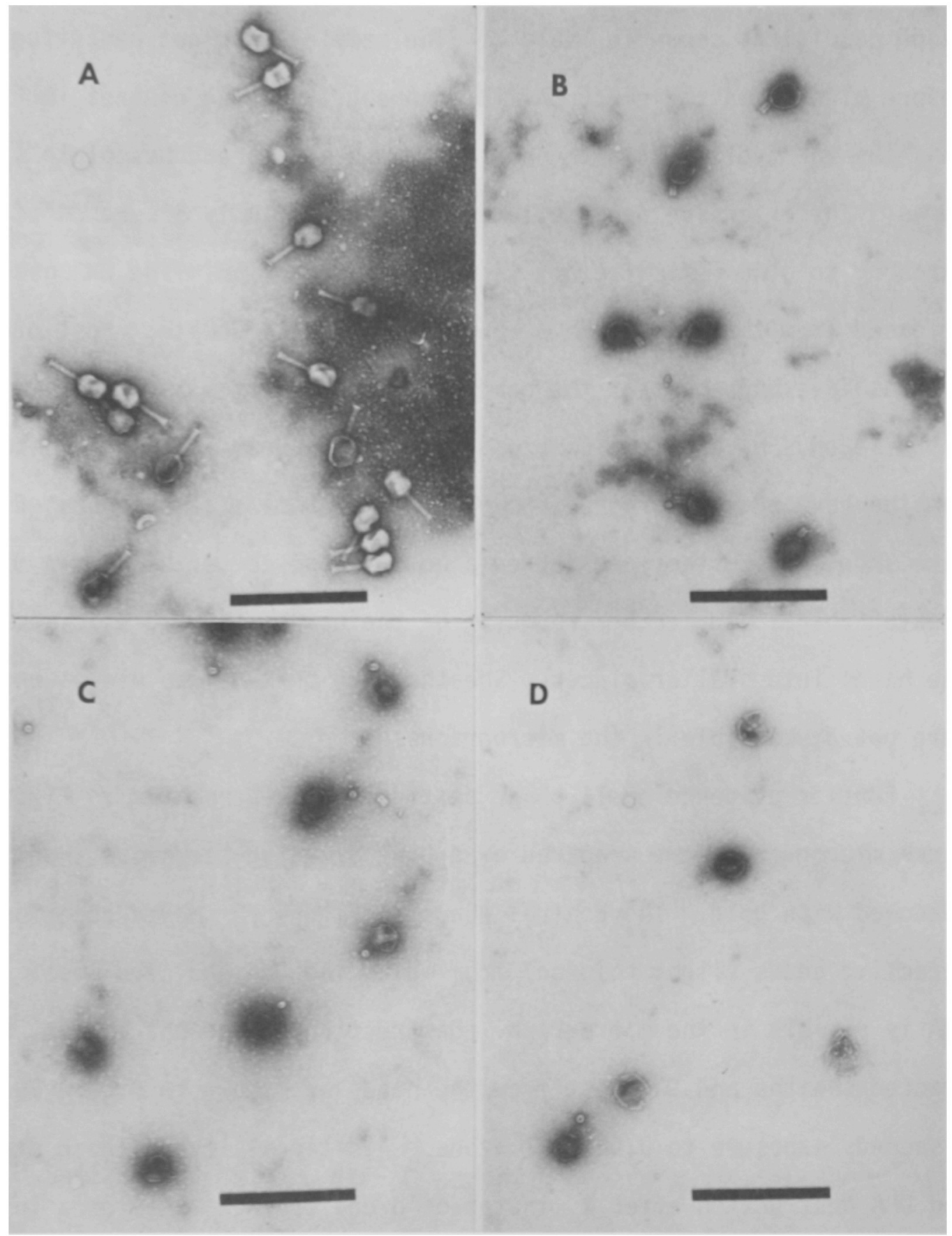

Figure 6. Electron micrographs of control phage $T 4(A)$ and phage which were treated with an initial ozone residual of $0.46 \mathrm{mg} / 1$ for 5 seconds (B), 30 seconds (C) and 120 seconds (D) Stained with 2 percent uranyl acetate. Exposure to ozone for 5 seconds caused sheath contraction, loss of baseplate and loosening of bond where tail joins head.

Heads were partially broken after 120 seconds exposure. Bars $=0.4 \mu \mathrm{m}$. 


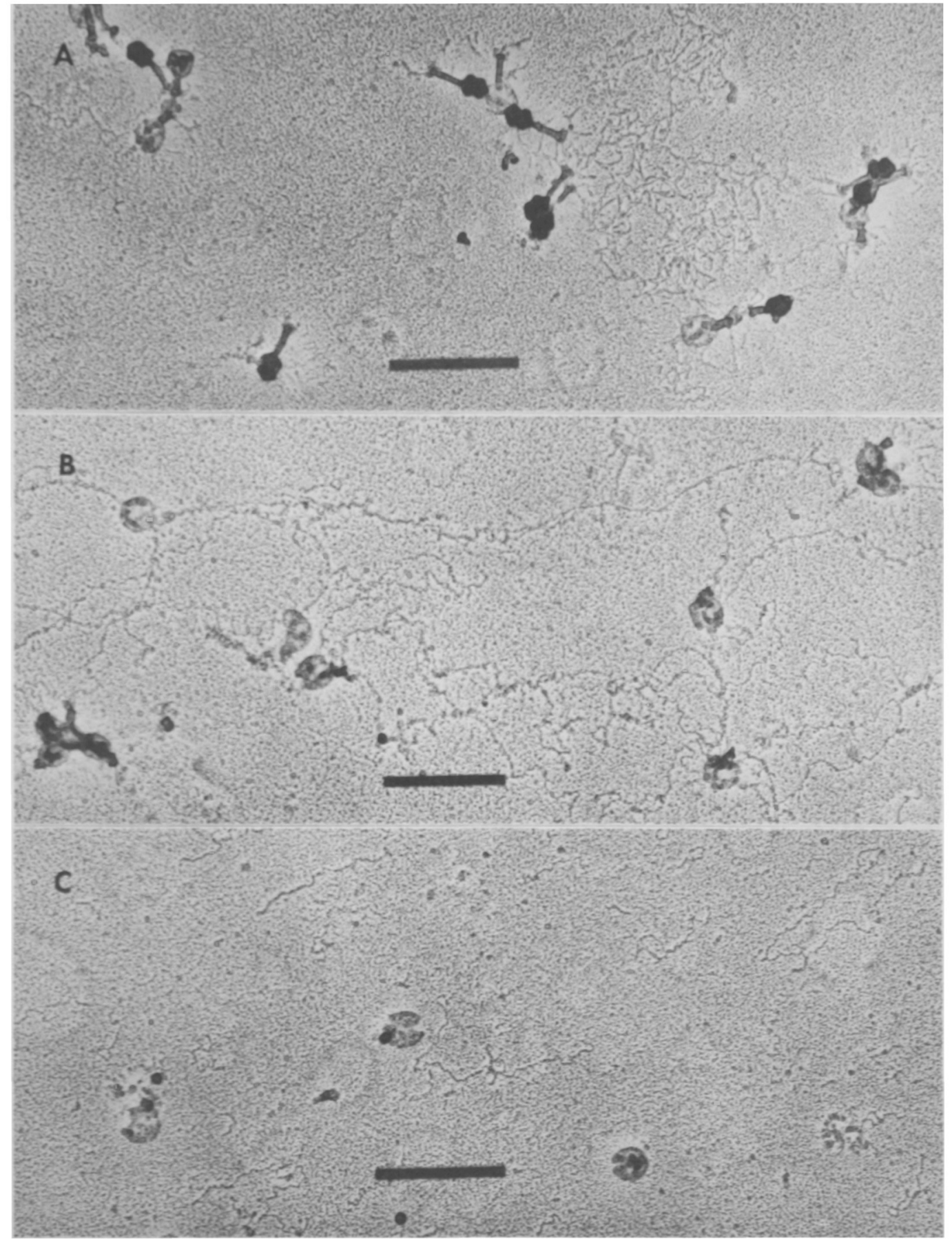

Figure 7. Electron micrographs of control phage $T 4(A)$ and phage treated with an initial ozone residual of $0.46 \mathrm{mg} / 1$ for 5 seconds (B) and 120 seconds (C). Rotary shadowed with gold. Control phage show some damaged phage with lost DNA. After ozone exposure for 5 seconds sheath contraction, head damage and DNA loss have occurred. Additional head destruction and DNA loss have occurred after 120 seconds. Bar = $0.4 ; \mathrm{m}$. 


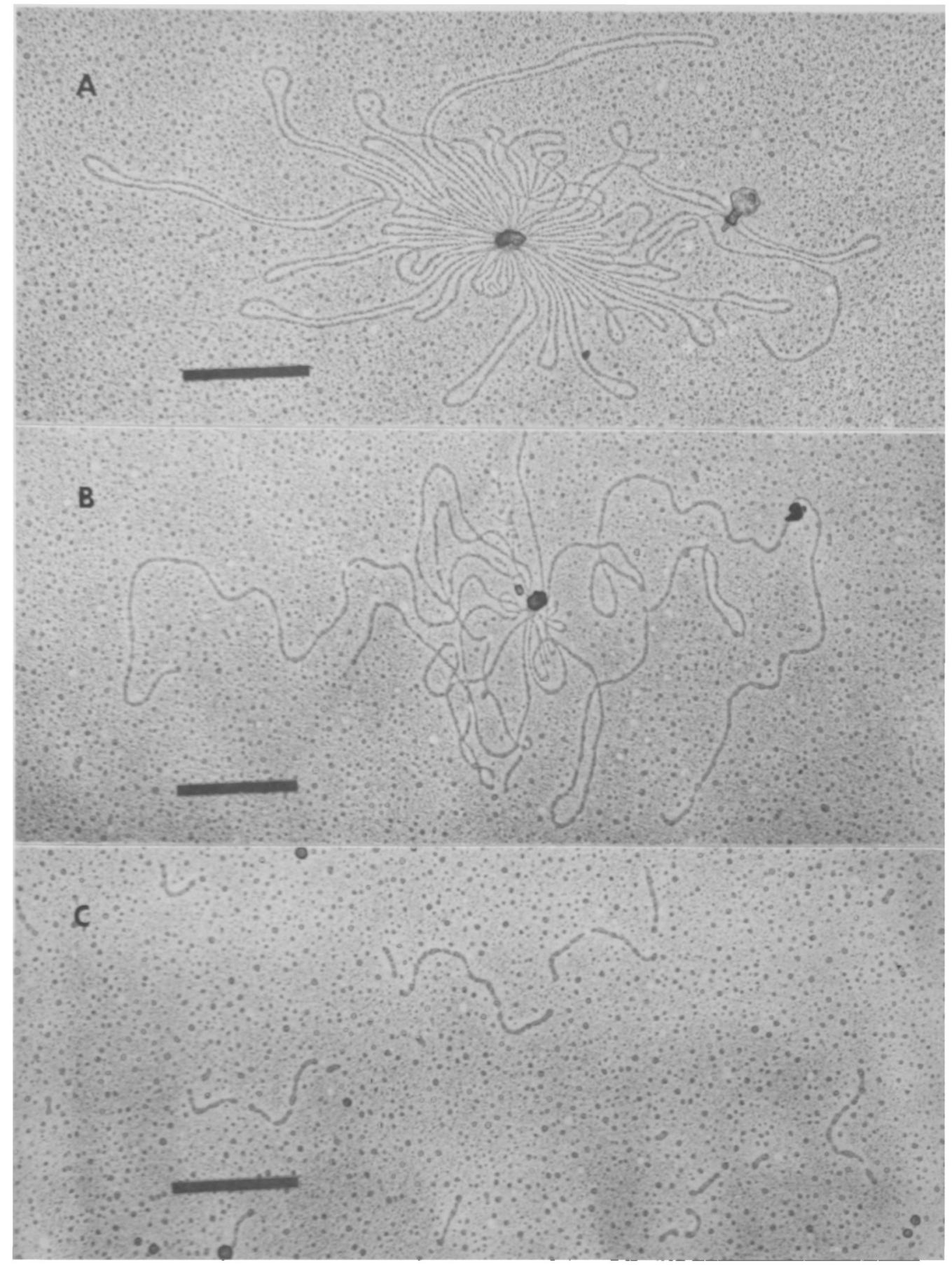

Figure 8. Electron micrographs of control phage and DNA (A) and phage and DNA after 5 seconds (B) and 120 seconds (C) exposure to ozone with an initial residual of $0.46 \mathrm{mg} / 1$ : Some damaged control phage with intact DNA were observed in A. DNA breakage has occurred after 5 seconds of exposure to ozone with very extensive breakage after exposure for 120 seconds. Bar $=0.4 \mathrm{im}$. 
5 seconds have occurred in the DNA molecule shown in Figure $8 B$. The extensive breakage of the DNA in Figure $3 C$ was typical of the DNA seen after exposure to ozone for 120 seconds.

\section{DISCUSSION}

A small amount of organic matter in solution can cause rapid dissipation of ozone and decreased inactivation rate of the test organisms To meet tinis demand, the ozonation system used in this study was carefully constructed with stainless steel and teflon tubing and the system calibrated to produce ozone concentrations as low as $0.01 \mathrm{mg} / 1$ All glassware and solutions for this study were made ozone-demand free. The ozone reactors were closed during mixing of the samples and the residual ozone was evaluated at the time of sampling.

Inactivation of the bacteriophage $f 2$ was demonstrated during this study by a quick reaction with a low concentration of ozone, as suggested by Venosa (33) Only 5 seconds were needed to inactivate 5 logs of the f2 with $0.09 \mathrm{mg} / \mathrm{l}$ ozone, but a longer time was required to completely inactivate the $10^{9} \mathrm{PFU} / \mathrm{ml}$ initially present $(10$ minutes with $0.8 \mathrm{mg} / 1$ ozone) Walsh et al (34), inactivating $f 2$ wit'i ozone, also observed an initial quick inactivation followed by a slower inactivation rate. The inactivation kinetics of the phage revealed a two-stage action of the ozone. Katzenelson et al. (11) thought their two-stage phenomenon was due to clumping of 0.5 to 1.0 percent of their poliovirus 1 There is evidence (37) that aggregation of some enteric viruses can reduce the inactivation rate by protecting the viruses from contact with disinfectants. The $\mathrm{f} 2$ phages were stored at $-70^{\circ} \mathrm{C}$ and thawed just prior to use in order to reduce any possible changes in their sensitivity to ozone as 
suggested by Katzenelson and Biedermann (10). In the $f 2$ phage stock as well as the diluted phage samples used in this study, aggregation was not detected by electron microscopy.

The $f 2$ phages were widely distributed throughout the sucrose gradient after sedimentation in both the ozone-treated and untreated phage samples At a concentration of about $10^{4} \mathrm{PFU} / \mathrm{ml}$ or less, the radioactivity was too low to be counted in CPM. This can be explained by the calculation of $79 \times 10^{5}$ PFU/CPM in the fraction of the control phage which showed peaks in both PFU and radioactivity. A minor peak in the 3rd fraction of the control phage was thought to be RNA, since a similar peak was observed in the gradient of the naked RNA sample which had been used as a reference. Leakage of the RNA from some phages may possibly have occurred during the thawing and dilution procedures of the phage stock since electron micrographs of the control sample revealed a few damaged phage particles.

The electron micrographs of the ozone-treated phages showed breakdown and alteration of the phage particles with the extent of the damage proportional to the concentration of ozone and the period of reaction time. The lightly treated f2 phage showed some deformed particles and large pieces of the broken capsids, whereas constant sized subunit particles were observed in the heavily treated phages. These subunits resemble the $11 \mathrm{~S}$ subunits of the bacteriophage $\mathrm{f2}$ (38) and $\mathrm{R} 17$ (19) which had been obtained by treated the phages with $4 M$ guanidine hydrochloride at neutral pH. Damage of the protein coat by ozonation has been reported in both RNA containing poliovirus (26) and DNA containing bacteriophage $9 \times 174$ (6). These changes are also supported by the absorbance changes of the proteins and amino acids (16) when treated with ozone. Mudd et al. 
(16) reported that proteins with susceptibie amino acid residues were inactivated directly by reaction of ozone and that cysteine, tryptophan, and methionine were the most susceptible among the amino acids Tryptophan and methionine were also demonstrated (25) to be particularly sensitive to ozone The breakdown of the $\mathrm{f} 2$ phage by ozonation can thusly be explained since the coat proteins contain cysteine, tryptophan, and methionine. The T4 phage demonstrated a very rapid loss of structural integrity. Within 5 seconds tail sheaths had contracted, DNA and base plates were lost, and head and DNA destruction had occurred. This behavior parallels that of the action of ozone on the f2 phage.

About $10^{6} \mathrm{PFU} / \mathrm{ml}$ of infectious RNA was recovered by phenol extraction from about $10^{10} \mathrm{PFU} / \mathrm{ml}$ of $\mathrm{f2}$ phages. The infectious RNA was evaluated for the presence of the phages with intact host bacteria and no plaques were produced. Both naked RNA and the RNA isolated from the previously ozonetreated phages were prepared from the same number of phages and diluted to react with ozone under the same conditions so that the same volume for the final preparation of the RNA could be directly compared for titration of infectivity and radioactivity. Few reports are available on the effect of ozone on RNA. Christensen and Giese (4) and Scott (27) reported that both purines and pyrimidines were changed by ozonation in their UV absorbancy Pyrimidine base also reacts with ozone $(4,24)$, with thymine being more susceptible to ozone than cytosine or uracil If it is true that among the pyrimidine bases, uracil is not affected by ozone, the f2 phage RNA should be more resistant to ozone than DNA.

The results obtained in this study show that ozone breaks the protein capsid of the $f 2$ phage to many subunits, liberating RNA into the solution and disrupting adsorption to the host pili. The RNA in the intact phage 
was less inactivated by ozonation than whole phages, but more inactivated than the naked RNA. This suggests that the coat protein may be involved in the inactivation of the RNA, probably by a secondary shearing reaction of the RNA with the protein molecules modified Dy ozonation. The RNA extracted from the $f 2$ phages prior to and after ozone treatment retained their infectivity to the spheroplasts after ozonation in spite of some reduction.

The T4 bacteriophage was rapidly broken and its DNA released to the bulk solution. Data are not available to show whether the DNA had been altered within the protein capsid as was shown for the f2. The DNA after its release to the water was quickly attacked by the ozone and rapidly lost its infectivity. The DNA inactivation rate appeared similar to that of the intact $T 4$ phage unlike that of the $f 2$ phage. Christensen and Giese (4) have shown that DNA is more susceptible to alteration by ozone than is RNA.

This research has shown that ozone attacks the $\mathrm{f2}$ and $\mathrm{T} 4$ in a manner such that their nucleic acids are released to the bulk solution. This release occurs after the coat proteins or organelles of the viruses are attacked by the ozone and disrupted. RNA is subsequently inactivated at a rate less than that of the intact phage while DNA is inactivated at the same rate as the intact phage.

Our results suggest that the RNA of enteric viruses may retain their infectivity after liberation from the viral particle during ozonation of water and wastewater, if they are inactivated by ozone in the same manner as the f2 phage.

\section{Comparative Inactivation Mechanisms}

Comparative data which are available in the literature on the inacti- 
vation mechanisms of the principal disinfectants which are available for use in drinking water have been summarized in Table 3 . The data from Reisser, et al. (26) and from the present study indicate that virus inactivation with ozone occurs by a loss of the capsid protein structure with subsequent release of nucleic acid. DNA is subsequently readily inactivated but RNA is inactivated at a slower rate. Attachment of the viruses undergoing ozonation to their host cells is inhibited. The investigators using chlorine showed that RNA was degraded within the capsid and subsequently released to the water Attachment of the virus to the cell was not inhibited. 0liveri, et al (21) showed that iodine reacts with the viral protein but not with RNA since the inactivated $f 2$ bacteriophage was not inactivated nor was naked RNA inactivated by iodine. Bromine appears to damage the capsid protein with subsequent loss of RNA to the water 01 iveri, et al (21) showed that the RNA from inactivated virus was inactivated with bromine at a slower rate than the whole phage, al though naked RNA was inactivated at the same rate as the intact phage.

In sumary, ozone, chlorine and bromine appear to inactivate nucleic acid (RNA) within the virus with the virus capsid readily broken and the RNA lost to the water. DNA is very readily destroyed with ozone. Iodine appears to react with protein but does not react with RNA.

\section{CONCLUSIONS}

The following conclusions can be drawn from this research:

(1) Ozone inactivates the $\mathrm{f} 2$ and $T 4$ bacteriophages by attacking the protein capsid, liberating the nucleic acid and inactivating the nucleic acid. 
TABLE 3

COMPARATIVE VIRUS INACTIVATION MECHANISMS

\begin{tabular}{|c|c|c|c|c|c|c|}
\hline Type & $\begin{array}{r}\text { Disinfectant } \\
\text { Conc. } \\
\mathrm{mg} / \mathrm{l}\end{array}$ & Virus & $\begin{array}{l}\text { Cell } \\
\text { Attach- } \\
\text { ment }\end{array}$ & $\begin{array}{l}\text { Nucleic } \\
\text { Acid }\end{array}$ & Mechanism & Reference \\
\hline \multirow[t]{3}{*}{$0_{3}$} & $?$ & Polio 2 & Inhibited & $?$ & Viral proteins destroyed. & Reisser et al. (26) \\
\hline & $\begin{array}{l}.09 \mathrm{mg} / 1 \text { for } \\
5 \mathrm{sec} \text {. } \\
.80 \mathrm{mg} / 1 \text { for } \\
30 \mathrm{sec} \text {. }\end{array}$ & $f 2$ & Inhibited & Inactivated & $\begin{array}{l}\text { Caps id broken. } \\
\text { RMA from inactivated virus less inactivated than } \\
\text { whole phage but more than naked RNA }\end{array}$ & This study \\
\hline & $\begin{array}{l}.46 \mathrm{mg} / 1 \text { for } \\
120 \mathrm{sec} .\end{array}$ & T4 & Inhibited & Inactivated & $\begin{array}{l}\text { Tail sheaths triggered. Tails and heads separated. } \\
\text { DNA released and inactivated. }\end{array}$ & This study \\
\hline \multirow[t]{3}{*}{$\mathrm{Cl}_{2}$} & $\begin{array}{l}2 \mathrm{mg} / 1 \text { for } \\
5-60 \mathrm{sec} \text {. }\end{array}$ & f2 & $\begin{array}{l}\text { Not } \\
\text { Inhibited }\end{array}$ & Inactivated & $\begin{array}{l}\text { RNA from inactivated virus inactivated at same rate } \\
\text { as whole phage at pH } 5.5,7.5 \text { and } 10.5 \text {. Naked RNA } \\
\text { inactivated at same rate as whole phage at pH } 5.5 \\
\text { and } 7.5 \text { but much faster at } 10.6 \text { than } 10.5 \text {. }\end{array}$ & 0livieri et al. (21) \\
\hline & $\begin{array}{l}1 \mathrm{mg} / 1 \text { for } \\
60-240 \text { sec. }\end{array}$ & Polio 1 & $\begin{array}{l}\text { Not } \\
\text { Inhibited }\end{array}$ & Inactivated & $\begin{array}{l}\text { RNA degraded into fragments within capsid and re- } \\
\text { leased. Virus inactivation occurred before release. } \\
\text { RNA from intact virus exposed to } \mathrm{Cl}_{2} \text { was not altered } \\
\text { (based on centrifugation). Empty capsids conforma- } \\
\text { tional state not altered. (pH 7.0) }\end{array}$ & $0^{\prime}$ Brien \& Newman (18) \\
\hline & $\begin{array}{l}.18-1.1 \mathrm{mg} / 1 \\
\text { for } 15 \cdot \mathrm{sec}\end{array}$ & Polio 1 & $?$ & $?$ & $\begin{array}{l}\text { RNA released to water. Capsid broken to small } \\
\text { pieces at highest } \mathrm{Cl}_{2} \text {. }\end{array}$ & Floyd et al. (7) \\
\hline$I_{2}$ & $\begin{array}{l}50 \mathrm{mg} / 1 \text { for } \\
300-900 \mathrm{sec}\end{array}$ & $f 2$ & $?$ & $\begin{array}{l}\text { Not } \\
\text { Inactivated }\end{array}$ & $\begin{array}{l}\text { Results suggest } I_{2} \text { reacts with viral protein } \\
\text { (tyrosine). RNA from inactivated phage not inacti- } \\
\text { vated. Naked RNA not inactivated with } I_{2} \text { (pH 7.0). }\end{array}$ & 01 ivieri et al. (21) \\
\hline \multirow[t]{2}{*}{$\mathrm{Br}_{2}$} & $\begin{array}{l}15 \mathrm{mg} / 1 \text { for } \\
300-600 \mathrm{sec}\end{array}$ & f2 & $?$ & Inactivated & $\begin{array}{l}\text { RNA from inactivated virus inactivated at slower rate } \\
\text { than whole phage. Naked RNA inactivated at same rate } \\
\text { as virus (pH } 7.5 \text { ). Inactivation thought to be reac- } \\
\text { tion with virai protein (pH } 7.5 \text { ). }\end{array}$ & Olivieri et al. (21) \\
\hline & $\begin{array}{l}.2-.4 \mathrm{mg} / 1 \\
\text { for } 60-240 \\
\text { sec. }\end{array}$ & Reo 3 & $?$ & $\begin{array}{l}\text { Probably } \\
\text { Inactivated }\end{array}$ & $\begin{array}{l}\text { Protein capsid damaged. RNA lost. RNA evidently } \\
\text { not viable (pH 7.0). }\end{array}$ & Sharp et al. (29) \\
\hline
\end{tabular}


(2) The RMA from the $f 2$ bacteriophage is at least partially inactivated before its release from the capsid. The rate of this inactivation is slower than the whole phage but faster than naked RNA exposed to ozone.

(3) DNA released from the T4 bacteriophage is rapidly inactivated by ozone at about the same rate as the intact phage. 


\section{LITERATURE CITED}

1 Adams, M.H. 1959. Bacteriophages Interscience Publishers, Inc., NY

2. Berg, G. 1970. Integrated approach to the problem of viruses in water p. 339-364. In Proc. National specialty conference on disinfection. Amer. Soc. Civil Engineer, NY

3. Brinton, C.C., Jr., and H. Beer. 1967 The interaction of male-specific bacteriophage with F pili. p. 251-289. In J.S. Colter and W. Paranchych (ed.), The molecular biology of viruses. Academic Press, NY

4. Christensen, E., and A. Giese. 1954. Changes in adsorption spectra of nucleic acids and their derivatives following exposure to ozone and ultraviolet radiations. Arch. Biochem. Biophys. 51:208-216.

5. Cramer, W.N., K. Kawata, and C.W. Kruse. 1976. Chlorination and iodination of poliovirus and 22 . J. Water Pollut. Control Fed. 48:61-76.

6. DeMik, G., and I. DeGroot. 1977. Mechanism of inactivation of bacteriophage $9 \times 174$ and its DNA in aerosols by ozone and ozonized cyclohexene. J. Hyg. Camb. 78:199-211

7 Floyd, R.D., G. Sharp and J.D. Johnson. 1979. Inactivation by Chlorine of single poliovirus particles in water. Environ. Sci Technol 13: 438-442.

8. Hofschneider, P.H., and H. Delius. 1968. Assay of M12 phage RNA infectivity in spheroplasts. P. 880-886. In L. Grossman and K. Moldave (ed.), Methods in enzymology vol. XII. Nucleic acids, part B. Academic Press, NY

9. Hsu, Y.C., S. Nomura, and C.W. Kruse. 1960. Some bactericidal and virucidal properties of iodine not affecting infectious RNA and DNA. Amer J. Epi demiol. 82:317-328.

10. Ketzenelson, E., and N. Biedermann. 1976. Disinfection of viruses in sewage by ozone. Water Res 10:629-631

11. Katzenelson, E., B. Kletter, and H.I. Shuval. 1974. Inactivation kinetics of viruses and bacteria in water by use of ozone. J. Amer Water Works Assoc. 66:725-729.

12. Keller, J.W., R.A. Morin, and T.J. Schaffernoth. 1974. Ozone disinfection pilot plant studies at Laconia, NH. J.Amer. Water Works Assoc. 66: 730-733.

13. Kleinschmidt, A.K. 1968. Monolayer techniques in electron microscopy of nucleic acid molecules. p. 361-377 In L. Grossman and K. Moldave (ed.), Methods in enzymology, vol XII, Part B. Academic Press Inc., NY 
14. Loeb, $T$, and N.D. Zinder 1961 A bacteriophage containing RNA. Nat'i Acad. Sci U.S. 47:282-289.

15. Majumdar, S.B., W.H. Ceckler, and 0.J. Sproul 1973. Inactivation of polioviruses in water by ozonation. J. Water Pollut. Control Fed. $45: 2433-2443$.

16. Mudd, J.B., R. Reavitt, A. Ongun. and T $T$ McManus. 1969. Reaction of ozone with amino acids and proteins. Atmospheric Environment. 3:669681

17 Nebel, C., R.D. Gottschling, R.L. Hutchison, T.J. McBride, D.M. Taylor, J.L. Pavoni, M.E. Tittlebaum, H.E. Spencer, and M. Fleischman. 1973. Ozone disinfection of industrial-municipal secondary effluents. J. Water Pollut. Control Fed. 45:2493-2507

18. O'Brien, R.T. and J. Newman. 1979. Structural and compositional changes associated with chlorine inactivation of polioviruses. Appl Environ. Microbiol 38:1034-1039.

19. O'Callaghan, R., R. Bradley, and F Paranchych. 1973. Controlled alterations in the physical and biological properties of RI7 bacteriophage induced by guanidine hydrochloride. Virology 54:476-494.

20. Oeschger, M.P, and D. Nathans. 1966. Differential synthesis of bacteriophage-specific proteins in MS2-infected Escherichia coli treated with actinomycin. J. Mol Biol 22:235-217

21 Olivieri, V.P., C.W. Kruse, Y.C. Hsu, A.C. Griffiths, and K. Kawata. 1975. The comparative mode of action of chlorine, bromine, and iodine on f2 bacterial virus. p. 145-162. In J.D. Johnson (ed.), Disinfection water and wastewater Ann Arbor Science, Ann Arbor, MI

22. Pavoni, J.L., M.E. Tittlebaum, H.T Spencer, M. Fleischman, C. Nebel, and R. Gottschling. 1972. Virus removal from wastewater using ozone. Water Sew. Horks. 119:59-67

23. Poynter, S.F.G., J.S. Slade, and H.H. Jones. 1973. The disinfection of water with special reference to viruses Wtr Trtmt. and Exam. 22:194-208.

24. Prat, R., C. Fofre, and A. Cier 1968. Effects de l'hypochlorite de sodium, de 1 'ozone et des radiations ionisontes sur les constituants pyrimidiques d'escherichia coli Ann. Ins. Pasteur. 114:595-607

25. Previero, A., M.A. Coletti-Previero, and P Jolles. 1967 Localization of non-essential tryptophan residues for the biological activity of lysozyme. J. Mol Biol 24:261-268.

26. Riesser, V.W., J.R. Perrich, B.B. Silver, and J.R. McCammon. 1976. Possible mechanism of poliovirus inactivation by ozone. p. 186-192. In Forum on ozone disinfection. International Ozone Institute, Syracuse, NY 
27 Scott, D.B.M. 1975. The effect of ozone on nucleic acids and their derivatives. p. 226-240. In W.J. Blogoslawski and R.G. Rice (ed.), Aquatic applications of ozone. International Ozone Institute, Syracuse, NY.

28. Shah, P., and J. McCamish. 1972. Relative resistance of poliovirus 1 and coliphage $f 2$ and $T 2$ in water. Appl Microbiol 24:652-659.

29. Sharp, D.G., R. Floyd and J.D. Johnson. 1975. Nature of the surviving plaque-forming unit of reovirus in water containing bromine. Appl. Microbiol. 29:94-101

30. Shechter, H. 1973. Spectrophotometric method for determination of ozone in aqueous solutions. Water Res. 7:729-739.

31 Snustad, D.P. and D.S. Dean. 1971 Genetics experiments with bacterial viruses. W.H Freeman and Co., San Francisco, CA.

32. Sommerville, R.C., and G. Rempel. 1972. Ozone for supplementary water treatment. J. Amer. Water Works Assoc. 64:377-382.

33. Venosa, A.D. 1972. Ozone as a water and wastewater disinfectant: a literature review. p. 82-100. In F.L. Evans III (ed.), Ozone in water and wastewater treatment. Ann Arbor Science, Ann Arbor, MI.

34. Walsh, D.S., C.E. Buck and 0.J. Sproul 1980. Ozone inactivation of floc associated viruses and bacteria. J. Environ. Engr Div., Am. Soc. Civil Engr. 106, (In press).

35. Weber, K., and W. Konigsberg. 1975. Proteins of the RNA phages. p. 5184. In ii.J. Zinder (ed.), RNA phages Cold Spring Harbor Laboratory, Cold Spring Harbor, NY.

36. Yamamoto, K.R., and B.M. Alberts 1970. Rapid bacteriophage sedimentation in the presence of polyethylene glycol and its application to large-scale virus purification. Virology 40:734-744.

37 Young, D.C., and D.G. Sharp. 1977. Poliovirus aggregation and their survival in water. Appl. Environ. Microbiol. 33:168-177.

38. Zelazo, P., and R. Haschemeyer 1969. Specific dissociation of bacteriophage $f 2$ protein to an $11 \mathrm{~S}$ component. Biochemistry. 8:3587-3592. 